DOI: 10.34015/2523-4552.2019.2.11

удк 343.8

Крикушенко О. Г., кандидат юридичних наук, заслужений юрист України, начальник Адміністрації Державної кримінально-виконавчої служби України e-mail: krk_aleksandr@ukr.net ORCID ID: 0000-0001-6470-2851

\title{
ТРАНСФОРМАЦІЯ ПОГЛЯДІВ НА ПРОЦЕС ВИКОНАННЯ ТА ВІДБУВАННЯ ПОКАРАННЯ У ВИДІ ПОЗБАВЛЕННЯ ВОЛІ
}

У статті здійснено історико-правовий огляд етапів формування і трансформації інститутів виконання та відбування покарання у виді позбавлення волі, акцентовано увагу на тих видозмінах, що відбулися упродовж XX - початку XXI ст.

Ключові слова: виконання покарання; покарання у виді позбавлення волі; політико-правова думка.

В статье осуществлен историко-правовой обзор этапов формирования и трансформации институтов исполнения и отбывания наказания в виде лишения свободы, акцентировано внимание на изменениях, произошедших в течение XX - начала XXI вв.

Ключевые слова: исполнение наказания; наказание в виде лишения свободы; политико-правовые учения.

Постановка проблеми. Історичні дослідження сфери виконання та відбування покарання у виді позбавлення волі часто бувають надмірно політизовані або відрізняються однобоким суб'єктивним поглядом на проблему, що розглядається безвідносно до загального історичного державно-правового тла. Можна лише згадати фундаментальну «Історію царської тюрми» М. М. Гернета, який у 30-40-х роках минулого століття в період масових сталінських репресій змальовував «жахи» царської каральної системи.

На складнощі історичних досліджень в означеній сфері звертав увагу відомий український вчений професор В. М. Трубніков, вважаючи, що спроби покласти в основу історичної періодизації час прийняття законів або інших нормативноправових актів, які визначають зміст i спрямованість кримінально-виконавчого законодавства в той чи інший етап розвитку держави, не мають необхідної методологічної бази. А коли ми звертаємося до аналізу таких складних і багатоаспектних соціальних явищ, як злочин i покарання, то їх оцінка не має ані державних, ані інших кордонів [1, c. 22-23].

Постановка завдання. Мета дослідження - провести історикоправовий огляд етапів формування і 
трансформації процесу виконання та відбування покарання у виді позбавлення волі, акцентувавши увагу на тих видозмінах, що відбулися упродовж XX - початку XXI ст.

Аналіз останніх досліджень та публікацій. В історії правової думки проблеми злочину і покарання займали традиційно вагоме місце в роботах видатних мислителів і філософів, починаючи ще з Аристотеля. Кожна історична епоха приносила своє розуміння «справедливого» покарання. У наукових працях класиків кримінального права I. Фойницького, М. Таганцева, О. Кістяківського та інших значну увагу звернуто на питання історії зародження та трансформації окремих видів покарань i процедури їх виконання.

У вітчизняній правовій науці однією з перших до цієї проблематики звернулася професор Т. Денисова. Продовжуючи традиції класичної наукової школи, авторка провела системне дослідження кримінального покарання, проблем його призначення, виконання та відбування, використовуючи його кримінальноправовий, кримінологічний та кримінально-виконавчий аналіз на базі сучасного хронологічного підходу щодо періодизації історії вчень про державу і право [2, с. 29; 3, с. 9].

До історичних витоків системи виконання покарань звертався і знаний український учений, який намагався відродити пенітенціарну ідею як мету покарання, - Г. Радов. За його редакцією видано декілька томів «Хрестоматії з історії пенітенціарної системи України» [4].

В останні десятиріччя дедалі більше істориків права та вчених у галузі кримінально-виконавчого права звертаються до історії станов- лення інституту покарання у різні історичні епохи та еволюції формування кримінально-виконавчої системи, зокрема І. Іваньков [5], П. Ісаков [6], І. Левчук [7], О. Неалов [8], В. Пальченкова [9], В. Россіхін [10], О. Сокальська [11], А. Степанюк [12], М. Шуп’яна [13], М. Яцишин [7; 14] та інші. Однак поза увагою авторів залишається процес трансформації поглядів на виконання та відбування покарання у новітній період у загальноєвропейському контексті, натомість їх дослідження зосереджені переважно на імперському та радянському періодах, що не дає можливості виробити необхідні рекомендації та прогнози для визначення векторів розвитку сучасної вітчизняної системи виконання та відбування покарання у виді позбавлення волі.

Виклад основного матеріалу. Сучасний історичний хронологічний підхід, спираючись на загальнонаукові (діалектичний, соціальний, плюралістичний, герменевтичний) методи вивчення історії не виключає, а з необхідністю враховує і використовує інші підходи. Формаційний підхід визначає змістовну характеристику державного устрою: рабовласницький, феодальний, буржуазний, соціалістичний, постсоціалістичний. Цивілізаційний підхід охоплює, у свою чергу, більш масштабні уявлення про існування Східної та Європейської цивілізацій і відповідно Східної та Західної традиції держави і права.

Традиційно щодо періодизації розвитку системи виконання покарань у виді позбавлення волі вітчизняна наука використовує періодизацію, запропоновану Д. Тальбергом, у якій історичні періоди зведені до 
трьох: каральний, філантропічний та політичний, за критерієм розвитку та реалізації принципу ідеї гуманізму в сфері виконання та відбування кримінальних покарань [15, с. 3-4].

Перший, «каральний», сягає найдавніших часів, коли покарання виходило 3 міфологічних, пізніше теологічних поглядів, про «кару небесну» і до XVII ст. У найдавніший період покарання у виді позбавлення волі сприймалося радше як перетворення людини у невільника, раба. Як спосіб покарати за злочин ув'язнювати особу було досить невигідно. Утримували в ув'язненні до суду або до сплати боргу. Тривале утримання в ув'язненні знаних осіб, князів на Русі лише підкреслює давній зв'язок цього виду покарання 3 повагою/визнанням людських чеснот і їх значенням для інших. У ранніх християн обмеження волі у домі церковному було пов'язано з покутою винуватця, що заклало паростки покаяння злочинця в місцях позбавлення волі: виправних будинках і тюрмах у майбутньому.

Усвідомлення свободи як однієї зі знакових невідчужуваних цінностей особистості в епоху Ренесансу, а далі Просвітництва, поєднане з тенденцією гуманізації покарання, зумовило визначення позбавлення волі як одного $з$ основних видів покарання. Хоча, як відомо, воно мало різноманітні форми: вигнання, заслання, тюремне ув'язнення, утримання у виправному закладі.

Отже, другий - «філантропічний» період пов'язаний із поширенням європейських гуманістичних ідей Ж. Руссо, Ч. Беккаріа, І. Бентама, Дж. Говарда, Ч. Ломброзо та ін.).

Аналіз ідеї-принципів, сформованих 1764 p. одним із засновників класичної школи кримінального права Ч. Беккаріа в його загальновідомій роботі «Про злочини і покарання», відкриває сучасним і майбутнім дослідникам еволюційний підхід до формування поглядів на трансформацію процесу виконання та відбування кримінального покарання.

Серед принципів-ідей Ч. Беккаріа, які залишаються актуальними до сьогодення, пропонується звернути увагу на такі:

- необхідність постійного пошуку більш ефективних заходів впливу на злочинність;

- для запобігання злочинам потрібно, щоб закони були простими, зрозумілими і щоб уся сила нації була спрямована на їх захист;

- краще запобігати злочинам, ніж карати за їх скоєння;

- судді не мають влади тлумачити закон, тому що вони не є законодавцями;

- невідворотність покарання важливіша, ніж страх перед більш жорстким покаранням, але коли $\epsilon$ надія на безкарність;

- смертна кара не потрібна, тому що подає приклад жорстокості;

- довічне рабство замість смертної кари спроможне утримати від учинення злочину i найрішучішу людину;

- єдиним та істинним мірилом злочину $\epsilon$ шкода, яку він заподіє нації;

- чим швидше призначається покарання після вчинення злочину, тим це корисніше і справедливіше;

- мета покарання полягає в тому, щоб не дати можливості винному знову завдати шкоду суспільству і утримати інших від учинення злочину; 
- для досягнення мети покарання потрібно, щоб зло покарання перебільшувало вигоду від скоєного злочину [17].

Значна популярність твору Ч. Беккаріа у політичних та громадських колах розвинутих європейських країн та поширення його у Новому світі стали своєрідним поштовхом до філантропічного руху за реформування системи покарань та покращення умов утримання в тюрмах. Створювалися чисельні благодійні товариства, члени яких не лише інспектували в'язниці, а й розробляли проекти якісно нових тюремпенітенціаріїв (в США зусиллями Пенсильванського тюремного товариство вдалося звести перші в світі пенітенціарії - одиночні тюрми, що не знали аналогів та створити систему одиночного утримання, що увійшла в історію як Пенсильванська чи Філадельфійська система). Власне, на початку XIX ст. і зародилася сучасна тюрма як заклад, у якому злочинець відбуває покарання в умовах ізоляції поєднаних з відповідним «позитивним» впливом на його поведінку та свідомість.

Виключно «пенітенціарний» концепт, як він початково був задуманий, утримання злочинця, максимально його відмежувавши від колишнього «злочинного» оточення, 3 метою спокути гріха-злочину через спілкування з богом, досить швидко в розвинутих індустріальних країнах зазнав фіаско. Натомість на перший план виступили ідеї трудової зайнятості засуджених, їх навчання, підготовка до майбутнього соціальнокорисного життя, що і заклади основи майбутньої ресоціалізації.

Третій - «політичний» період, пов'язаний $з$ використанням кримі- нального покарання як одного із засобів захоплення, зміцнення та утримання державної влади. Попри фактичні трагедії, масові вбивства та ув'язнення цілих народів, все ж слід визнати, що на цьому етапі в процесі розвитку кримінально-правової ідеї покарання стає засобом захисту суспільства і виправлення соціальнонебезпечної особистості. I застосування різноманітних засобів захисту суспільства безпосередньо стає залежним від соціальної небезпеки злочинця [17, с. 165].

Професор Т.Денисова звертає увагу на те, що, крім специфічних ознак покарання як найбільш суворої форми реалізації кримінальної відповідальності, саме функції кримінального покарання є втіленням у реальності об'єктивних можливостей того чи іншого виду покарання в організації суспільних відносин та зв'язків, що виникають у процесі призначення та виконання кримінальних покарань [3, с. 13].

Сучасна національна кримінальної правова система України, яка детермінує кримінально-процесуальну, кримінально-виконавчу i кримінологічну системи, у сукупності визначає загальну систему кримінальної юстиції України як систему «постсоціалістичного типу», для якого характерним є переважна охорона прав та інтересів особистості, що базується на ліберальній ідеології прав людини [18, с. 902].

Лише з часу проголошення незалежності та суверенітету України (1991 р.) фактично розпочався сучасний або новітній етап історії побудови правової, демократичної, соціальної, суверенної та незалежної держави. Ухвалення Конституції України (1996 р.) Кримінального 
кодексу України (2001р.), Кримінально-виконавчого кодексу України (2003 р.), Кримінального процесуального кодексу України (2012р.) закріплюють законодавче визначення поняття кримінального покарання та його мети (ст. 50 КК), види кримінальних покарань (ст. 51 КК), порядок призначення кримінального покарання (ст. 62, 124 КУ, а також відповідні статті КК та КПК), порядок і умови виконання та відбування кримінальних покарань (КВК).

Ураховуючи те, що предметом дослідження $є$ еволюція процесу виконання та відбування кримінального покарання у виді позбавлення волі, слід зауважити, що згідно зі статтею 63 КК позбавлення волі на певний строк полягає в ізоляції засудженого та поміщенні його на певний строк до кримінальновиконавчої установи закритого типу, позбавленні волі від 1 до 15 років, за винятком випадків, передбачених Загальною частиною КК України.

Дискусія про скасування смертної кари як виду кримінального покарання має багаторічну і навіть мінливу історію. Питання в тому, чому смертна кара як винятковий вид кримінального покарання продовжує застосовуватися в багатьох країнах світу (навіть у США офіційно виконуються різноманітні види вбивств засуджених до смертної кари в окремих штатах країни за обвинувальними вироками суду) i, усупереч висновкам сучасної кримінологічної науки, знищує не злочинність, а саме людину, яка навіть не завжди $є$ злочинцем.

Як свідчать непоодинокі факти засудження і страти осіб, які пізніше визнані невинуватими у вчиненні злочину, за який вони були покарані, безпомилкової системи кримінальної юстиції у світі ще не існує.

Тому покарання у виді позбавлення волі $\epsilon$ безумовною альтернативою смертної кари, навіть коли суспільна правосвідомість вимагає їі поновлення.

Трагедії людства середини XX ст. вплинули і на еволюцію системи покарань. Створення Нюрнберзького Міжнародного військового трибуналу та засудження не конкретних фізичних осіб, а керівництва цілої країни стало абсолютно новим явищем в історії правових систем країн світу. Після цього розпочався процес консолідації зусиль міжнародного співтовариства щодо вироблення нових безпекових норм та гарантій дотримання прав людини. Жахливі наслідки Другої світової війни спонукали світову спільноту до розроблення та прийняття загального міжнародного договору про права людини, тому що чинний на той час Статут ООН не досить повно визначав саме права людини.

Спираючись на Загальну декларацію прав людини, на I Конгресі $\mathrm{OOH}$ із запобігання злочинності та поводження 3 правопорушниками (1955 р.), прийнято Мінімальні стандартні правила поводження 3 ув'язненими, які вперше звернули увагу міжнародної спільноти на окремий інститут державного примусу - кримінальне покарання у виді позбавлення волі [19].

Міжнародна правосуб'єктність СРСР та ті процеси, що відбувалися 3 ініціативи міжнародного співтовариства у повоєнний період, примусили керівництво СРСР переглянути кримінальну політику держави в бік гуманізації покарання, у результаті чого відбулося переосмислення засад 
засад і пріоритетних завдань системи виконання покарань, ухвалено низку нових нормативно-правових актів, що регламентували цю сферу [20, с. $126-129]$.

Міжнародно-правові інституції змушені були шукати більш ефективні засоби протидії викликам і криміногенним наслідкам глобалізації та інформатизації. Серед них - еволюційний перехід від декларативних, формально-юридичних міжнародно-правових актів до взаємоузгоджених дій щодо створення незалежного постійного Міжнародного кримінального суду (МКС).

17 липня 1998 року в Римі на Дипломатичній конференції повноважних представників під егідою ООН ухвалено Римський статут Міжнародного кримінального суду. Фактично, це була спроба запропонувати міжнародній спільноті проект Модельного кримінального, кримінальнопроцесуального і кримінальновиконавчого судочинства 3 урахуванням національних відмінностей у цій сфері. На відміну від інших країн Німеччина у зв'язку 3 прийняттям Римського статуту Міжнародного кримінального суду у 2000-2002 рр. прийняла шість федеральних законів, серед яких - Закон про імплементацію Римського статуту до чинного законодавства Німеччини і Закон про співробітництво з Міжнародним кримінальним судом.

Найбільш суттєвим є той факт, що МКС як основні види покарань встановлює такі: позбавлення волі на певний строк (на строк до 30 років); довічне позбавлення волі [21].

Наступним концептуальним положенням $є$ те, що Президія МКС має право в будь-який час призначати одного із суддів для здійснення інспекційної перевірки будь-якого пенітенціарного центру, у якому утримуються звинувачені або засуджені. Після проведення інспекційної перевірки призначений для цього суддя надає Президії та Секретарю МКС конфіденційну доповідь, у якій висловлює свої висновки та рекомендації. За результатами вивчення й оцінки означеної доповіді Президія може прийняти будь-яке рішення або дії, необхідні для поновлення порядку і забезпечення безпеки в пенітенціарному центрі [22].

Зазначені міжнародні акти та діяльність відповідних міждержавних установ створюють своєрідні тренди/дороговкази у сфері формування національної кримінальної політики. У цьому процесі суттєвим фактором став i соціальноекономічний чинник. Відповідний підхід щодо дослідження функціональних зв'язків між злочином і покаранням свого часу використав видатний економіст Г. Беккер, який у роботі «Злочин і покарання (економічний підхід)» визначив необхідні інформаційні параметри та функції, на яких повинна базуватися державна політика у сфері протидії злочинності із застосуванням кримінальноправового примусу.

Серед них учений пропонує спиратися на такі:

- кількість злочинів;

- збитки від учинення злочинів;

- залежність розміру збитків від кількості злочинів;

- покарання, які перебільшують збитки (дохід) від учиненого злочину; чинців; 
- витрати на боротьбу зі злочинністю;

- вид і форма покарання.

Г. Беккер сформулював основи соціально-економічного підходу в дослідженні саме процесу виконання та відбування покарання у виді позбавлення волі. Його дослідження також підкреслює актуальність загальновідомих положень, які вже набули рівня аксіом - скорочення злочинності забезпечується не суворістю покарання, а його невідворотністю за вчинення злочину, а також коли держава, завдяки своїй економічній спроможності і просвітницькій діяльності, доведе, що вільна праця на свободі дає людині більш вигідні результати для забезпечення свого рівня життя, ніж доходи від злочинної діяльності [23].

На сучасному етапі спостерігаємо серед європейських країн певну уніфікацію, чи тенденції до неї, кримінального, процесуального, пенітенціарного

(кримінальновиконавчого) законодавства; створення загальноєвропейських силових структур, узгодження практики винесення судових вироків та призначення кримінальних покарань. При цьому, євроінтеграція не передбачає радикального вторгнення у сферу національної кримінальної юстиції країн-членів ЄС. Навпаки, вони здійснюють інтеграцію шляхом політики кооперації, координації та гармонізації кримінально-правової сфери [24, с. 125-147].

Висновки. Ураховуючи історично мінливий характер форми та змісту кримінального покарання у виді позбавлення волі та проєвропейський вектор розвитку кримінально-виконавчої системи України на сучасному етапі, найбільш доречним видається вивчення та запозичення досвіду розвитку цього інституту державного примусу 3 другої половини XX сторіччя до нашого часу в європейських країнах та на міждержавному рівні

Міжнародна спільнота після ретельного, всебічного вивчення чинних у різних країнах світу систем кримінального покарання визначає лише один його вид - позбавлення волі (на певний час або довічне).

Сукупність наведених висновків та окремих питань, які визначають основні концептуальні підходи до дослідження процесів виконання та відбування покарання у виді позбавлення волі, повинні надалі сприяти оновленню науково-теоретичних і організаційно-управлінських основ ефективного, справедливого, рівноправного, безпристрасного, публічного і відкритого застосування кримінального покарання у виді позбавлення волі як найбільш суворого заходу державного та міжнародноправового примусу.

\section{Список використаних джерел}

1. Трубников В. М. Уголовно-исполнительное право Украины. Общая часть. Харьков : Рубикон. 1998. 370 с.

2. Денисова Т. А. Кримінальне покарання та реалізація його функцій : автореф. дис. доктора юрид. наук: 12.00.08. Київ : Ін.-т держави і права ім. В. М. Корецького НАН України, 2011. 36 с.

3. Денисова Т. А. Покарання і кримінально-правовий, кримінологічний та кримінально-виконавчий аналіз : монографія. Запоріжжя : КМУ, 2007. 288 с. 
4. Хрестоматія з історії пенітенціарної системи України / упорядн.: Г. О. Радов, І. І. Резнік. Київ : РВВ КІВС, 1998. Т. 1, Ч. 1. 414 с.; Т. 1, Ч. 2.402 с.; Київ : Говард Пресс, 1999. Т. 2, Ч. 1. 456 с.; Т. 2. Ч. 2. Донецьк : ТОВ «Східний видавничий дім», 2011. $510 \mathrm{c}$.

5. І Іваньков І. Історико-правовий аналіз діяльності органів і установ виконання покарань на території України (кінець 19 - середина 20 сторіччя) : монограф.; за заг. ред. д-ра юрид. наук, проф. І. Г. Богатирьова. Бровари : ХмЦНТЕІ, 2010. 208 с.

6. І Ісаков П. Сільськогосподарське виробництво виправно-трудової системи УСРР у 1923 році. Вісник Пенітенціарної асоціації України. 2018. № 2. С. 15-29.

7. Яцишин М. М., Левчук I. О. Місця позбавлення волі у Волинській губернії Російської імперії наприкінці XVIII - початку XX ст. (історико-правове дослідження) : монографія. Луцьк : Східноєвропейський нац. ун-т ім. Лесі Українки, 2018. 160 с.

8. Неалов 0.П. Організаційно-правове забезпечення реалізації тюремної реформи в Російській імперії в другій половині XIX - на початку XX ст. (на матеріалах українських губерній) : автореф. дис ... канд. юрид. наук. Харків, 2003. 20 с.

9. Пальченкова В. М. Трансформація громадського контролю за виконанням покарань: історико-правовий аналіз : монограф. Запоріжжя : Акцент, 2013. 524 с.

10. Россіхін В.В. Організаційно-правові засади діяльності пенітенціарної системи в Україні (1917-1991 рр.). Запоріжжя : КПУ, 2015. 368 с.

11. Сокальська О. В. Інститут тюремного ув'язнення на українських землях у X-XVI ст.: історико-правовий аналіз. Часопис Київського університету права. 2013. № 4. С. 38-43; Сокальська О. В. Польські пенітенціарні концепції початку ХІХ століття. Часопис Київського університету права. 2017. № 4. С. 38-43.

12. Степанюк А. Х. Історичний досвід становлення в Україні установ виконання покарань закритого типу. Вісник Пенітенціарної асоціації України. 2018. № 2. C. $148-159$.

13. Шуп'яна М. Ю. Система покарань за австрійським кримінальним кодексом 1852 року та практика їх застосування у Східній Галичині. Львів, 2017. 252 с.

14. Яцишин М. М. Історико-правові засади кримінально-виконавчої політики України : монограф. Луцьк : Волинськ. нац. ун-т ім. Лесі Українки, 2010. 448 с.

15. Тальберг Д. Тюремная литература и тюрьмоведение. Москва : Университетская типография (М. Катков), 1876. С. 3. 289 c.

16. Беккариа Ч. О преступлениях и наказания. Москва : Госюриздат, 1939.

17. Пашуканис Е. Б. Избранные произведения по общей теории права и государства. Москва : Наука, 1980. 270 с.

18. Баулін Ю. В. Вибрані праці. Харків : Право, 2013. 928 с.

19. Мінімальні стандартні правила поводження з в'язнями , прийняті Генеральною асамблеєю ООН 30.03.1955 року. URL: http://www.un.okg/ru/documents/ deel_conv/conventions/prison.shtml. (дата звернення: 10.06.2019).

20. Бараш Є. Ю. Організаційно-правові аспекти становлення виправнотрудової системи Харківщини в повоєнний період. Вісник Пенітенціарної асоціації України. 2018. № 4. С. 125-136. DOI: 10.34015/2523-4552.2018.4.04.

21. Римський статут міжнародного кримінального суду. URL: http://zakon3.rada.gov.ua/laws/show/995_588 (дата звернення: 20.05.2019).

22. Регламент Міжнародного кримінального Суду /ICC-BD/01-01-04 URL: https://www.icc-cpi.int/NR/rdonlyres/B920AD62-DF49-4010-8907-E0D8CC61EB A4/277532/ICCBD010104_Russian.pdf (дата звернення: 12.05.2019).

23. Becker G. Essays in the economics and punishment. W. M. Landes. N. Y., 1974. 
24. Vogel J. The European Integrated Criminal Justice System and Its Constitutional Framework. Maastricht journal of European and comparative law. Vol. 12. 2005. № 2. P. 125147.

\section{References}

1. Trubnikov, V. M. (1998). Ugolovno-ispolnitelnoe pravo Ukrainy. Obshaya chast. Harkov: Rubikon [in Ukrainian].

2. Denisova, T. A. (2011). Kriminalne pokarannya ta realizaciya jogo funkcij. (Avtoref. dis. doktora yurid. nauk). In.-t derzhavi i prava im. V. M. Koreckogo NAN Ukrayini [in Ukrainian].

3. Denisova, T. A. (2007). Pokarannya i kriminalno-pravovij, kriminologichnij ta kriminalno-vikonavchij analiz : monografiya. Zaporizhzhya : KMU [in Ukrainian].

4. Radov, G. O. (Red.). (1998-2011). Hrestomatiya $z$ istoriyi penitenciarnoyi sistemi Ukrayini. Kiyiv, Doneck : RVV KIVS, TOV «Shidnij vidavnichij dim» T. 1, Ch. 1-2, T. 2, Ch. 1-2 [in Ukrainian].

5. Ivankov, I. (2010). Istoriko-pravovij analiz diyalnosti organiv $i$ ustanov vikonannya pokaran na teritoriyi Ukrayini (kinec 19 - seredina 20 storichchya) : monograf.; za zag. red. d-ra yurid. nauk, prof. I. G. Bogatirova. Brovari: HmCNTEI [in Ukrainian].

6. Isakov, P. (2018). Agricultural production of the correctional-labor system of the Ukrainian Soviet Socialist Republic in 1923. Bulletin of the Penitentiary Association of Ukraine, (2), 15-29 [in Ukrainian].

7. Yacishin, M. M., Levchuk, I. O. (2018). Miscya pozbavlennya voli u Volinskij guberniyi Rosijskoyi imperiyi naprikinci HVIII - pochatku HH st. (istoriko - pravove doslidzhennya) : monografiya. Luck: Shidnoyevropejskij nac. un-t im. Lesi Ukrayinki [in Ukrainian].

8. Nealov, O. P. (2003). Organizacijno-pravove zabezpechennya realizaciyi tyuremnoyi reformi $v$ Rosijskij imperiyi $v$ drugij polovini XIX - na pochatku XX st. (na materialah ukrayinskih gubernij). (Avtoref. dis ... kand. yurid. nauk). Harkiv [in Ukrainian].

9. Palchenkova, V. M. (2013). Transformaciya gromadskogo kontrolyu za vikonannyam pokaran: istoriko-pravovij analiz: monograf. Zaporizhzhya: Akcent [in Ukrainian].

10. Rossihin, V.V. (2015). Organizacijno-pravovi zasadi diyalnosti penitenciarnoyi sistemi v Ukrayini (1917-1991 rr.). Zaporizhzhya: KPU [in Ukrainian].

11. Sokalska, O. V. (2013). Institut tyuremnogo uv'yaznennya na ukrayinskih zemlyah u X-XVI st.: istoriko-pravovij analiz. Chasopis Kiyivskogo universitetu prava, 4, 3843; Sokalska, O. V. (2017). Polski penitenciarni koncepciyi pochatku XIX stolittya. Chasopis Kiyivskogo universitetu prava, 4, 38-43 [in Ukrainian].

12. Stepanyuk, A. H. (2018). Historical experience in the development of prisons of closed type in Ukraine. Bulletin of the Penitentiary Association of Ukraine, (2), 148-159 [in Ukrainian].

13. Shup'yana, M. Yu. (2017). Sistema pokaran za avstrijskim kriminalnim kodeksom 1852 roku ta praktika yih zastosuvannya u Shidnij Galichini. Lviv [in Ukrainian].

14. Yacishin, M. M. (2010). Istoriko-pravovi zasadi kriminalno-vikonavchoyi politiki Ukrayini: monograf. Luck: Volinsk. nac. un-t im. Lesi Ukrayinki [in Ukrainian].

15. Talberg, D. (1876). Tyuremnaya literatura $i$ tyurmovedenie. Moskva: Universitetskaya tipografiya [in Russian]. Russian].

16. Bekkaria, Ch. (1939). O prestupleniyah i nakazaniya. Moskva: Gosyurizdat [in

17. Pashukanis, E. B. (1980). Izbrannye proizvedeniya po obshej teorii prava $i$ gosudarstva. Moskva: Nauka [in Russian].

18. Baulin, Yu. V. (2013). Vibrani praci. Harkiv: Pravo [in Ukrainian]. 
19. Minimalni standartni pravila povodzhennya $\mathrm{z}$ v'yaznyami , prijnyati Generalnoyu asambleyeyu OON 30.03.1955 roku. URL: http://www.un.okg/ru/documents/ deel_conv/conventions/ prison.shtml. (accessed: 10.06.2019) [in Ukrainian].

20. Barash, Ye. (2018). Organizational and legal aspects of development of the correctional-labor system of the Kharkiv region in the post-war period. Bulletin of the Penitentiary Association of Ukraine, (4), 125-136. DOI: 10.34015/2523-4552.2018.4.04 [in Ukrainian].

21. Rimskij statut mizhnarodnogo kriminalnogo sudu. URL: http://zakon3.rada.gov.ua/laws/show/995_588 (accessed: 20.05.2019) [in Ukrainian].

22. Reglament Mizhnarodnogo kriminalnogo Sudu /ISS-VD/01-01-04 URL: https://www.icc-cpi.int/NR/rdonlyres/B920AD62-DF49-4010-8907-E0D8CC61EB A4/277532/ICCBD010104_Russian.pdf (accessed: 12.05.2019) [in Ukrainian].

23. Becker, G. (1974). Essays in the economics and punishment. W. M. Landes. N.Y. [in English].

24. Vogel, J. (2005). The European Integrated Criminal Justice System and Its Constitutional Framework. Maastricht journal of European and comparative law. Vol. 12, 2, 125-147 [in English].

O. Krykushenko, PhD in Law, Honored Lawyer of Ukraine, Head of the Administration of the State Criminal-Executive Service of Ukraine

e-mail: krk_aleksandr@ukr.net; ORCID ID:0000-0001-6470-2851

Transformation of views on the process of enforcement
and serving the sentences related to the imprisonment

The article provides the historical and legal overview of the stages of formation and transformation of the penal establishments, especially those changes, which occurred during the XX - beginning of the XXI century.

It has been determined that in the recent period the process of transforming the views on enforcement and serving the sentences related to the imprisonment in the pan-European context remains out of the authors' attention. Their researches are focused mainly on the imperial and soviet periods, which makes it impossible to make the necessary recommendations and prognosis to determine the vectors for the development of the modern system of imprisonment in Ukraine.

Considering the historically changing nature of the form and content of the criminal penalties in the form of imprisonment and the pro-European vector of the Ukrainian penal system development at the present stage, it is appropriate to study and take the experience of the developed European state bodies on enforcement of sentences since the second half of the XX century till present time, as well as on the interstate level.

The international community, after the thorough study of the criminal penal systems of different countries of the world, considers imprisonment (for the concrete term or life-long) as the only appropriate type of criminal punishment.

The totality of the above findings and individual issues, which determine the main conceptual approaches to the study of the execution and serving the sentences, should further contribute to the renewal of the scientific, theoretical and organi- 
zational-managerial foundations of the effective, fair, equitable and impartial criminal punishment in the form of imprisonment as the most severe measure of the state and international legal enforcement.

Keywords: execution of punishment; punishment in the form of imprisonment; political and legal opinion.

Надійшла до редакції 07.08.2019 